\title{
Research on Intangible Cultural Heritage and Traditional Cultural Protection Mechanism
}

\author{
Jinhong Tao \\ Changchun Sci-Tech University, Changchun, Jilin, 130600
}

Keywords: Intangible Cultural Heritage, Traditional Cultural, Protection Mechanism

\begin{abstract}
With the development of economy and the intensification of global integration, the role of culture in national development has become more and more prominent. Intangible cultural heritage as an important part of China's cultural resources, more and more attention by the community, its protection is more attention. This paper explores the value of intangible cultural heritage protection and traditional Chinese cultural heritage, and excavates the intangible cultural heritage by using the methods of logical and historical reunification and comparative research and other methods to discuss the protection of intangible cultural heritage.
\end{abstract}

\section{Introduction}

In the long river of history, mankind has created a rich material and cultural heritage and intangible cultural heritage. Both are the components of cultural resources, is a country, a national spirit embodied, behind the possession of a variety of traditional values, moral and national spirit, with social value, scientific value, historical and cultural value. For a long time, the material and cultural heritage has always been the attention of everyone, its protection work started much more than the intangible cultural heritage. Material cultural heritage is tangible, is the objective existence of the kind. Tangible objects in the course of the development of history is not easy to save, easy to be damaged, can spread the material and cultural heritage is very rare, this will lead to material cultural heritage of the national spirit of the show is not enough. Rather than the material cultural heritage can make up for this deficiency, intangible cultural heritage is mainly rely on people, as long as someone's existence, intangible cultural heritage there can be inherited opportunities. It is a nation, a civilization to identify their own important features, it witnessed the development process of all ethnic groups, is a valuable cultural resources. Therefore, the protection of intangible cultural heritage has been paid more and more attention. For the study of intangible cultural heritage, the academic circles have also discussed extensively. From the perspective of the protection of intangible cultural heritage, many scholars have elaborated from different aspects. However, at present, the academic circles mainly elaborated the methods of protecting the intangible cultural heritage, and deeply studied the protection of the intangible cultural heritage and the inheritance of Chinese traditional culture. There were not many precedents in the academic circles.

\section{The Status Quo of Domestic Protection of Intangible Cultural Heritage}

In order to vigorously promote the excellent traditional culture, our government attaches great importance to the protection of intangible cultural heritage and has done a lot of work. In 1979, China's Ministry of Culture, the State Ethnic Affairs Commission and the China Federation of Literary and Art Circles co-sponsored the work of compiling the "Ten Chinese Folk Literature and Art Circles". As of the end of 2004, 298 provinces have been drafted and 224 volumes have been published. The This work has preserved a large number of precious artistic resources, known as the contemporary culture of the "Great Wall". In the middle of the 20th century, in the face of the demise of many intangible cultural heritage, our government organized cultural workers to carry out investigation and rescue. In 1997, the State Council promulgated the Regulations on the Protection of Traditional Arts and Crafts, established a national assessment institution for traditional arts and 
crafts, which could protect a large number of traditional arts and crafts, and named more than 200 "Master of Arts and Crafts". The state also set up a "revitalization of the Kunquological Steering Committee", "the revitalization of Peking Opera Steering Committee", and the establishment of special funds to implement the national Kunqu art rescue, protection and support projects. A group of long traditions, ethnic style and local art characteristics of the township, the country was named the hometown of folk art, the hometown of characteristic art. Enhance the whole society on the protection of traditional cultural heritage awareness, encourage all over the intangible cultural heritage of finishing, research and development. Since 2002, the Ministry of Finance, the Ministry of Culture and other relevant departments launched the Chinese national folk cultural protection project, through a series of protection measures, the implementation of some important value and the dying of the intangible cultural heritage of the rescue protection. At present, China has identified 40 national pilot projects, various provinces and cities have also identified a number of protection projects, many local governments to develop relevant local government regulations, so that intangible cultural heritage protection law. Vice Minister of Culture Zhou Heping pointed out: "The local governments to establish heritage activities, for the heritage activities and personnel training to provide financial support and support education to carry out the popular national folk cultural activities, the provisions of the conditions of primary and secondary schools should be included in education and teaching Content and other measures, fruitful to carry out the protection of intangible cultural heritage.

\section{The Inheritance of Intangible Cultural Heritage to Chinese Traditional Culture}

Five thousand years of civilization history, for us left a rich culture. This includes not only the orthodox Confucian culture, but also all kinds of folk culture. Folk culture is based on the intangible cultural heritage, including folk literature, folk music, folk dance, traditional drama, folk art, acrobatics and athletics, folk art, traditional handicrafts, traditional medicine and folklore. Folk culture is rooted in the civil public, the orthodox Confucian culture is bound to penetrate into the people's lives, therefore, folk culture will be more or less influenced by the Confucian culture. During the period of Emperor Wu of Han Dynasty, Dong Zhongshu put forward the "abandonment of 100, Confucianism", and since then Confucianism has become orthodox thought. In order to strengthen the penetration of Confucianism into the popular people and to promote Confucianism in various ways, the rulers of the dynasties can popularize the Confucian culture and introduce them into the subconscious of people to regulate people's thoughts and actions and form the Chinese people A common habit of custom. Confucianism has thus become the basis of the entire Chinese culture, rooted in the hearts of every Chinese people. The strong implementation of the rulers, Confucian culture will continue to infiltrate, leading to the root of the non-material cultural heritage in the folk embodies a lot of Confucianism. Due to the restriction of economic and cultural conditions, the understanding of Confucian public thought is not from the saints' classics, more from the various forms of art such as novels, operas, folk songs and stories, folk proverbs, paper cutting, home New Year paintings and so on. People from these artistic images to understand the Confucian thought, influenced by the Confucian culture, it can be said that the people are living in the Confucian culture of the atmosphere, perhaps they themselves do not realize, but they see, hear, Most of them are Confucianism. It is so that the intangible cultural heritage virtually promotes the inheritance of Confucianism and is rooted in the hearts of the people.

\section{The Value of Intangible Cultural Heritage Protection}

"Intangible cultural heritage is a national traditional culture, with social value, historical and cultural value, tourism value and scientific value." People of all ethnic groups in China rely on rich imagination, creativity and artistic performance, in the thousands of years of history, To create and form a rich folk music, folk dance, traditional drama and folk art and other non-material cultural heritage. The artistic and cultural heritage of these performing arts is true, vivid and vividly reflecting the people's lifestyles, customs, national customs and aesthetic concepts in different 
regions and different historical periods and inherited the culture of all ethnic groups, their unique artistic style and Artistic charm deeply shocked people's mind, to the beauty of the enjoyment, has a high artistic aesthetic value.

And dynamic art corresponds to the art of static class. Including national costumes, folk art, national embroidery, ethnic traditional crafts and so on. Hezhe's dance has expanded the range of people's dynamic art, and the clothing of the Hezhe family has also expanded the enjoyment of people's static art. In every session of the "Wu Rigong" in the General Assembly, can bring people to enjoy the United States is not only songs and dance, He Zhe's national costumes will also make us feel novel. He Zhe's clothing production skills are very particular about the production process fine, mostly hand-made from hand. He Zhe's national costumes are bright, reflecting the national customs. Especially in the jump when the shaman wearing the "shaman hat", wearing the "Saili", more reflects the Hezhe traditional culture. Embroidery, this historic traditional folk art, has a very high aesthetic value. Known as the four famous embroidery, "Suzhou embroidery, Guangdong embroidery, embroidery, Shu embroidery" and Gu embroidery, Miao embroidery, aquarium embroidery and Tu Tuo embroidery are included in the first batch of national intangible cultural heritage list. Embroidery, it is the crystallization of hard work and wisdom of our people, with a high cultural taste. Suxi embroidery color, the color of the shade, shiny birds can listen to the sound, embroidered embroidery, embroidery, embroidery, embroidery, embroidery, embroidery, embroidery, embroidery, embroidery, embroidery, embroidery, embroidery, embroidery, embroidery Can run, embroidery can vivid "reputation.

"It is our duty and a wise move to attach the cultural heritage and protect our ancestors to our treasures and to pass them as much as possible to our children and grandchildren." The cultural heritage can be as an important event in the past or an important stage of development and character closely related evidence, is a wordless historical data, can tell us a national cultural history or a region of economic and cultural development history of the relevant content. It can be seen that cultural heritage has a historical and cultural value that can not be ignored. More importantly, the intangible cultural heritage has the characteristics of invisible, civil, oral and active, which shows the credibility of its historical and cultural values. It can make up for the official history of the history books and the lack of omissions and omissions, help people more real, more comprehensive, to understand the history and culture. China is composed of 56 ethnic groups of a large family, ethnic rich and splendid intangible cultural heritage makes the Chinese nation's cultural connotation more intense, more colorful, become the world's national culture in a wonderful work. Intangible cultural heritage represents a nation's unique culture, and this culture is the spirit of a nation. For a country, a nation, to maintain their own unique culture, is essential. The intangible cultural heritage has contributed to the diversity of the Chinese nation culture with its own characteristics. Intangible cultural heritage enriches the content of Chinese culture, can calmly face the impact of foreign culture. In the first article of the Universal Declaration on Cultural Diversity, UNESCO pointed out: "Cultural diversity is the source of communication, innovation and creation, and it is indispensable for human beings as biodiversity is essential for maintaining biological balance. In this sense, cultural diversity is a common heritage of mankind and should be recognized and affirmed from the interests of contemporary and future generations. "

Intangible cultural heritage as a valuable cultural resources, scientific and technological innovation can also play a huge role. Many non-material cultural heritage itself has a certain scientific value, if a reasonable transformation of its innovation, will create new scientific and technological achievements. The development of new technology is not necessarily the premise of the disappearance of traditional science and technology, on the contrary, we should learn from the nutrition, for the support of contemporary scientific and technological progress. For example, traditional Chinese medicine programs such as traditional Chinese medicine life and disease cognition, acupuncture and moxibustion, traditional Chinese medicine orthopedic therapy, Tong Ren Tang Chinese medicine culture and Hu Qingyu Tong traditional Chinese medicine culture are inherently contained in the traditional medicine project. , Has a high scientific composition. In the maintenance of the traditional basis for its reasonable innovation, to give the vitality of the times, to 
the world, establish an international brand image, which is more conducive to enhance the influence of our culture. In the face of international market competition, we should use and play to their strengths, build their own brand, strengthen the international influence, so that we can continue to enhance the international competitiveness of our culture. To protect the intangible cultural heritage, give full play to its influence, is conducive to improving the cultural quality of the whole nation, improve the level of civilization of the whole society; is conducive to the rapid economic development and promote regional economic harmonious development; is conducive to carry forward the national spirit, Cohesion. Thereby enhancing China's "soft power" to enhance China's comprehensive national strength, enhance international competitiveness, so that it is at the forefront of the world.

\section{Conclusion}

Intangible cultural heritage itself has a high artistic value, in the intangible cultural heritage protection has not been taken seriously, many non-material cultural heritage we do not understand. With the protection of intangible cultural heritage more and more attention, we also understand that more and more intangible cultural heritage, these high artistic value of the intangible cultural heritage, to expand our original artistic enjoyment. Strengthen the protection of intangible cultural heritage, but also conducive to the establishment of harmonious interpersonal relationships, enhance the "soft power", thereby enhancing China's comprehensive national strength. Intangible cultural heritage is both cultural resources, can also be transformed into economic resources, promote economic development in economically backward areas, in order to achieve regional economic and harmonious development.

\section{References}

[1] Xia Jianguo. The diversity and unity of contemporary world culture [J]. Journal of Changsha University of Science and Technology. 2009 (03)

[2] Liu Qian. Brief description of China's tangible cultural heritage protection [J]. Legal and social. 2009 (23)

[3] Qian Yinghua. Nationality long drum dance multi-cultural characteristics and social function [J]. Journal of Hebei Institute of Physical Education. 2009 (04)

[4] Yi Heng. Cultural sovereignty theory and the current national cultural soft power development strategy theory construction [J]. South China. 2009 (02)

[5] Wang Dandan. Cultural value of Xinjiang's intangible cultural heritage of ethnic minorities [J]. The forefront. 2009 (06)

[6] Chen Shoujun. The intangible cultural heritage research and its value [J]. Journal of Shanxi University of Finance and Economics. 2009 (S1) 